ИСТОРИЯ

DOI: 10.17805/trudy.2015.2.3

\title{
«НЕ Я НУЖЕН СЛУЖБЕ, СЛУЖБА - МНЕ». ПЕРЕХОД РУССКОЙ ВОЕННОЙ ЭЛИТЫ НА ГРАЖДАНСКУЮ СЛУЖБУ ПОСЛЕ НАПОЛЕОНОВСКИХ ВОЙН
}

\author{
О. И. Елисеева \\ (Московский гуманитарный университет)
}

\begin{abstract}
Аннотация: Статья посвящена особенностям процесса перехода военной элить Российской империи на гражданскую службу после 1813-1815 г2., по окончании Наполеоновских войн. Рассматриваются различные аспекты социализации высших офицеров в гражданской жизни, их взаимоотношения с другими группами дворянства.
\end{abstract}

Ключевые слова: история России, Российская империя, Наполеоновские войны, военная элита, гражданская служба.

\section{«SERVICE DOES NOT NEED ME, BUT I NEED SERVICE»: READJUSTMENT OF RUSSIAN MILITARY ELITE TO CIVIL SERVICE AFTER THE NAPOLEONIC WARS}

\author{
O. I. Eliseeva \\ (Moscow University for the Humanities)
}

\begin{abstract}
The article considers the peculiarities of the Russian Empire's military elite's readjustment from military to the civil service in the aftermath of the Napoleonic wars, starting from 1813-1815 years. We look at various aspects of senior officers' socialization in civilian life, as well as their relationships with other groups of the nobility.
\end{abstract}

Keywords: Russian Empire, Napoleonic Wars, military elite, civil service.

Фраза в заглавии статьи принадлежит герою 1812 г. и Заграничного похода русской армии, командующему Оккупационного корпуса во Франции, Михаилу Семеновичу Воронцову. В 1817 г. он задумался об отставке, но вот беда - Воронцов служил с 19 лет, к моменту расставания с корпусом ему было 36. Всю сознательную жизнь он провоевал то на Кавказе, то против Турции, то против Швеции и, наконец, долго - с чувством, с толком, с расстановкой - против Наполеоновской Франции.

Теперь покидать армию ему было сложно, помимо прочего, еще и по психологическим причинам. Михаил Семенович не знал жизни за пределами служебной субординации и системы приказов, им получаемых и им 
отдаваемых. Такие люди в отставке чувствовали себя рыбами, выброшенными на сушу. А уходить было надо: наступил долгожданный мир, apмия сокращалась, да и сами наши герои сильно устали на два десятилетия войн, были изранены, хотели немного пожить «для себя». Средства имелись. Ведь мы говорим о дворянах, следовательно, у каждого из них хоть худая деревенька, да имелась. Воронцов же вообще выглядел принцем 30 тыс. душ - целый корпус или маленькое государство.

Тем не менее... Страх, неуверенность, желание вернуться к привычной действительности. Судьба Михаила Семеновича - судьба целого поколения. Или нескольких поколений: на Великую войну попали и «старики» $1750-$ х гг. рождения, и совсем мальчики, появившихся на свет в середине $1790-$ х. Поговорим о них. Тем более что сами они писали о себе мало: разве что мемуары. Современный читатель знаком с этими людьми по литературным героям: муж Татьяны Лариной, Скалозуб, Максим Максимыч, князь Андрей Болконский.

Стоит поближе разглядеть их прототипов и понять, чем для них обернулось окончание великих войн с Францией. Какова была их судьба до и после кровавого рубежа.

Военная галерея Зимнего дворца полна изображений молодых генералов. В 1776 г. княгиня Е. Р. Дашкова, объясняла ректору Эдинбургского университета Уильяму Робертсону, почему ее 13-летний сын Павел должен немедленно стать студентом и пройти курс как можно скорее: «У нас, дабы чего-нибудь добиться, надобно... рано начать служить... Я не могу положить четыре года на учение моего сына, который еще совсем не служил, а затем два года положить на путешествия, что вкупе... приведет к тому, что он вступит в службу лишь 20 лет от роду» (Дашкова, 2001: 237). Поверим княгине. В полк, в полк, в полк - таков был девиз дворянской молодежи и ее предусмотрительных родителей. Петру Гриневу из «Капитанской дочки» «пошел семнадцатый годок», когда отец обеспокоился об его отправке в армию.

А. С. Грибоедов 1816 г. заметил: «...ныне большая часть генералов таких, у которых подбородок еще не опушился» (цит. по: Лотман, 2003: 727). Около тридцати генералы, участвовавшие в Наполеоновских войнах, разменивали обычно генерал-майорский чин - первый из обоймы генеральских. Для того, чтобы стать «полным» генералом, требовалось еще несколько лет выслуги, и многие, как М. С. Воронцов, ждали этого события годами, а ускользание «полного генеральства» становилось жгучей болью, вызванной личным не благоволением государя (Удовик, 2004: 146).

Раздраженный на собственные служебные неудачи Грибоедов утрировал. C «неопушенными подбородками» ходили не генералы, прапорщики и подпоручики. В собрании музея А. С. Пушкина в Москве есть два портрета 
кисти крепостного художника С. С. Свинцова, изобразившего шестнадцатилетних двоюродных братьев В. С. Апраксина и А. П. Строганова в 1812 и 1813 гг. (Карнухина, 2005: 22). Владимир Апраксин, любимый внук старой княгини Н. П. Голицыной - «princess Moustache» - прототипа графини в пушкинской «Пиковой даме», родился в 1796 г., накануне войны стал прапорщиком, служил в Кирасирском корпусе своего дяди князя Д. М. Голицына, принимал участие в битвах при Дрездене, Кульме, Лейпциге, Фершампенуазе, имел боевые награды и в возрасте 18 лет участвовал во взятии Парижа (Знаменитые россияне, 1996: 235). Его кузен Александр Строганов 17 лет от роду погиб при Краоне: на глазах у отца ему ядром оторвало голову. Его Пушкин в «Онегине» назовет «залетным птенцом».

Действительно, эти мальчики были на поле брани «залетными птенцами». Более всего в их портретах поражает несоответствие «взрослой» формы и наград с юными лицами. Над верхней губой Апраксина еще не усы - только тень. Лицо Строганова по-детски нежное. Он погиб, не начав бриться. Обоим мундиры с тяжелыми, точно веревочными, аксельбантами великоваты и выглядят, как школьная форма на вырост. Таким, вероятно, был и Петя Ростов из «Войны и мира» Л. В. Толстого «со своими веселыми черными глазами, свежим румянцем и чуть пробивающимся пушком на щеках».

В этих образах два варианта судьбы дворянина того времени: погибнуть, как Строганов, или благополучно миновать кровавый рубеж 1814 г., продолжать службу и, подобно Апраксину, стать генерал-майором, войти в императорскую свиту.

Кто им противостоял? Не следует думать, будто прославленные наполеоновские гренадеры первых призывов - с ними успели справиться вояки постарше, урожая 80-х гг. XVIII столетия. Сохранился портрет французского кирасирского лейтенанта Шарля Легранде кисти неизвестного художника, написанный в 1808 г. Перед нами мальчик не старше Апраксина и Строганова: крепкий и рослый, он уже годится носить увесистую кирасу, но лицо по-прежнему мальчишеское, небритое из-за отсутствия растительности. После 1813 г. основу армии Бонапарта составляли 16-17летние призывники, прошедшие только двухнедельную военную подготовку, - «марии-луизочки», как их дразнили острословы, поминая молодую жену императора Марию Луизу Австрийскую (Нерсесов, 2012a: 140).

Перечисление битв в послужных списках показывает, что юноши, родившиеся в середине 90-х гг. XVIII в., застали, главным образом, Заграничный поход русской армии. Войну они заканчивали в лучшем случае капитанами, а большинство - поручиками. Генеральские чины выслуживались ими уже после победы. Стараясь разбавить корпус офицеров, получивших отличия во время военных действий, Александр I был щедр 
на продвижения «списочных» и нарочно придерживал производство тех, кто отличился на поле брани. Такова была тактика императора в долгой, непростой игре с тайными обществами военных заговорщиков. Но генералов старшего поколения такие выдвиженцы очень раздражали. А.П.Ермолов, например, писал А. А. Закревскому с Кавказа, что в гвардии «печатают полковников, как ассигнации». «Истолкуй мне, почтенный Арсений, - обращался он к дежурному генералу Главного штаба, - какой злой дух понуждает вас производить подобных генералов? ...Они могут быть болванами для удобнейшей просушки с золотым шитьем мундиров?» (Сборник Русского ..., 1890: 300). Доходило до того, что Ермолов просто не отправлял подобных генералов к местам службы, а собирал в Тифлисе, предпочитая вести дела через проверенных офицеров среднего звена (Давыдов, 2005: 105).

Вернувшиеся из похода генералы 30-35 лет, чья юность была унесена войной, стремились наверстать упущенное, погулять напоследок. Они могли оказаться на тех же пирушках, что и молодой Пушкин, вместе с Онегиным участвовать в «шалостях», увиваться вокруг одних и тех же актрис. Это порождало у не служивших еще мальчиков иллюзию короткости, едва ли не панибратства.

Показательна история с эпиграммой молодого А.С.Пушкина на Алексея Федоровича Орлова, к тому времени генерал-майора, командира лейб-гвардии Конного полка. Он родился в 1788 г., участвовал в сражениях при Аустерлице, Бридланде, Витебске, Смоленске, Бородине, Люцене, Дрездене, Лейпциге, был семь раз ранен - о нем как раз можно сказать: «в сраженьях изувечен». Награжден золотым оружием за храбрость, многими русскими и иностранными орденами (Чукарев, 2005: 175).

Великая княжна Ольга, дочь Николая I, знавшая Орлова с детства, писала о ситуации уже 1840-х гг: «Орлов принадлежал к типу русского человека, который сам по себе полон противоречий. Временами он мог совершенно распускаться, не одевался по целым дням, ходил в старых ночных туфлях, не брал в руки ни книг для чтения, ни одной бумаги. Но если дело шло о каком-нибудь поручении... его старание и умение тонко вести самые сложные переговоры не знали себе равных. Во всех ситуациях он сохранял свободу своего ума, мужество и твердость, при этом не был ни дипломатом, ни солдатом. Он обладал тем, что отличает русского человека - готов ко всему, чего потребует царь» (Ольга Николаевна ..., , 2008: 374).

После войны Орлов и Пушкин оказались в одних и тех же компаниях, имели общих приятелей, хотя поэт был на девять лет моложе. В 1817 г. Александр Сергеевич подумывал о военной службе, Орлов рекомендовал свой полк. С. А. Соболевский, со слов самого поэта рассказывал: «В театре его подозвал к себе Алексей Федорович... и стал отговаривать его от по- 
ступления в гусары... а, напротив, предлагал служить в конной гвардии. Эти переговоры... ни к чему не привели, но были поводом к посланию», которое «у нас ошибочно принято считать посланием к Михаилу Федоровичу Орлову, так как с ним Пушкин впоследствии очень сблизился» (Coболевский, 2005: 391).

«Орлов с Истоминой в постели

В убогой наготе лежал.

Не отличился в жарком деле

Непостоянный генерал.

Не думав милого обидеть,

Взяла Лаиса микроскоп

И говорит: "Позволь увидеть,

Чем ты меня, мой милый...”»

Возможно, Пушкин, не терпевший покровительства «от равных» (Пушкин, 1962b: 160), решил поставить генерала на место. А, возможно, его испугало сделанное несколькими днями ранее предсказание о будущей гибели, часть которого уже начала исполняться на глазах. Но эпиграмма звучала особенно оскорбительно, если учесть, что Орлов до старости оставался дамским угодником. «Он выглядел очень молодцевато, был затянут, как во времена императора Александра I, напудрен и подтянут, он очень тяготился своей женой, которая была набожной плаксой, он же любил ухаживать, - вспоминала Ольга Николаевна. - ...Папа очень ценил его, так как он был прекрасным и понятливым работником... Всегда добродушный, всегда благодушный, он был желанным гостем у нас. Папа постоянно дразнил его и называл “mauvais sujet” [фр. 'шалопай’ - O. E.]. Часто приходилось искать его по крайней мере полчаса, прежде чем сесть за стол» (Ольга Николаевна ..., 2008: 373).

Нечто от «шалопая» есть и в пушкинской эпиграмме. Но одно дело внутренняя обстановка царской семьи, другое - дерзость 18-летнего, шапочно знакомого юноши. Заметно, что поэт старается держаться с генералом как бы на равных. Однако в глазах света Орлов ни по чинам, ни по возрасту ровней молодому Пушкину не был. Вскоре генералы почувствовали, что им пора «выйти из того положения, при котором какой-нибудь юноша мог трепать» их «по плечу и звать в неприличное общество» (Bересаев, 1986: 128). Они раньше младшей родни и приятелей, вроде Онегина, отказывались от лестных прозвищ «тверского Ловеласа» или «петербургского Вальмона» (Вульф, 2005: 369), вспоминали о возрасте и поторапливались обзавестись семьей.

Например, дама ставшая одним им прототипов Татьяны - Ольга Федоровна Брискорн - первым браком была замужем за молодцом и красавцем Яковом Александровичем Потемкиным, родившимся в 1781 г. Он 
успел повоевать при Аустерлице и Фридланде, генерал-майорство получил, как водится, в 1812 г., а к 1824 г. стал уже генерал-лейтенантом и носил звание генерал-адъютанта свиты. Женился Потемкин сравнительно поздно, 48-ми лет, в 1829 г., и был почти на тридцать лет старше своей 20-летней избранницы (Арабоглы, 2006: 81-82).

Сама О. Ф. Брискорн прибыла в Петербург «из глуши степных селений», из курского имения, где воспитывалась под присмотром строгой самовластной матери, которая и устроила брак. Ее единственным наставником был сельский священник. Попав в столицу, барышня выглядела запуганной и плохо образованной. После замужества Ольгу Федоровну представили ко двору, дали фрейлинский шифр и полюбили в сете за простоту и кротость: «Она красива, очень нежна, застенчива; все мы находим ее интересной» (Фикельмон, 2009: 178), - писала Долли Фикельмон.

Сам Яков Александрович после войны командовал лейб-гвардии Семеновским полком, отменил в нем телесные наказания, был обожаем офицерами и солдатами, пережил не благоволение Александра I, подозрения в либерализме, переводы в другие воинские части, статусом пониже, а затем на гражданскую службу. Он скончался в Житомире генералгубернатором Подольской и Волынской губерний.

В данном случае возраст - это судьба. Вернее разные линии судьбы. Рождение в 80-х, а не в середине 90-х гг. XIX в. многое значило для военного человека той поры. Второй муж Брискорн - Мейендорф олицетворял младшее армейское поколение. Но внутри поколения героев 1812 г. было третье, вернее самое первое звено - те, кто встретил еще республиканские войны с Францией. Из них нашим современникам наиболее известны М. А. Милорадович, А. П. Ермолов, П. И. Багратион, Н. А. Раевский, Д. И. Дохтуров. Самые старшие из них принимали участие еще в екатерининских кампаниях. Те, чьи годы рождения тяготели к началу $1770-\mathrm{x}$, сражались против повстанцев Т. Костюшко в Польше, затем в Персидском походе 1796 г. и, наконец, в Италии и Швейцарии вместе с А. В. Суворовым 1798-1799 гг. Там они оказались бок о бок с великим князем Константином Павловичем, который находился в армии под именем графа Романова и весь переход через Альпы совершил пешком, без одной подметки на сапоге (Нерсесов, 2012b: 150-153). Впоследствии суворовские «крестники», во всяком случае Милорадович и Ермолов, поддерживали именно кандидатуру Константина в качестве наследника престола и в момент воцарения Николая I их поведение выглядело очень двусмысленным.

В противовес им, Александр I, уже сделавший выбор в пользу иного претендента, старался укрепить позиции младших братьев генералами помоложе - И. Ф. Паскевичем, А. Х. Бенкендорфом, А. Ф. Орловым.

Примирить с уходом со службы наших героев могла бы семья, брак. 
После войны 1812 г. началась целая полоса свадеб. Но люди, прошедшие войну 1812 года, а вернее череду войн, начавшуюся еще за порогом XIX в., мыслили очень самостоятельно, редко поддавались опеке в таком важном вопросе как женитьба и уклонялись от «сделанных» браков. Еще в 1815 г. Воронцов писал своему кузену Д. П. Бутурлину, москвичу, прощупывавшему степень влияния родни на будущего главу клана: «Я разделяю ваш взгляд и чувствую, что подходящее устройство личной жизни и хозяйства было бы лучшим средством обеспечить себе счастливое будущее. Я был бы уже счастлив тем удовольствием, которое это доставило бы отцу и моим родственникам; но я не помышляю ни о браке по расчету, ни о браке устроенном другими. Нужно, чтобы это случилось само по себе, и чтобы я полюбил и оценил человека, желающего добра мне. За одно или два пребывания в России в мирное время я смог бы найти то, что мне нужно, без спешки. Сердце мое совершенно свободно, и я желал бы только, чтобы это могло устроиться с первого раза, поскольку время не молодит: не будучи старым, я начинаю седеть... это может не понравиться барышням, и они не захотят, может быть, иметь со мной дело» (Русский архив, 1912: 389). Бенкендорф тогда же признавался Воронцову, что «начал терять свою великолепную шевелюру» (Олейников, 2009: 170).

Друг Александра Христофоровича, служивший с ним в одном партизанском отряде, будущий декабрист Сергей Волконский, выбрав дочь фактически разоренного генерала Н. Н. Раевского, менее всего беспокоился о согласии своих столичных родных и более всего о семье Марии: «Давно влюбленный в нее, я, наконец, в 1824 году, решился просить ее руки... Не будучи уверенным, что получу согласие... я выставил причиною вымышленное расстройство моего здоровья и поехал на Кавказские воды с намерением, буде получу отказ, искать поступления на службу в кавказскую армию и в боевой жизни развлечь горе от неудачи в жизни частной» (Волконский, 1902: 414).

Люди, знавшие свет, прекрасно понимали, как он растлевает душу. У Толстого сказано о чувстве князя Андрея к Наташе Ростовой: «Как человек выросший в свете, он любил все, на чем не было отпечатка света». Молодые генералы двенадцатого года часто искали для себя не тронутых светом провинциалок. Едва встретившись с графиней Натальей Кочубей, дочерью министра и богатой невестой, Воронцов отверг ее (Удовик, 2004: 113). Позднее Наталья Викторовна, одна из юношеских муз Пушкина, вышла замуж за графа А. Г. Строганова генерал-майора императорской свиты. Этот брак был, как тогда говорили, «сделанным», и не мешал супругам искать иных радостей. В феврале 1830 г. Долли Фикельмон записала случай на маскараде: «Меня особенно потешил и забавлял весь вечер тот уникальный способ, которым я сумела заинтриговать Александра Стро- 
ганова. Ожидая какую-то даму, он принял меня за эту особу. С того момента от души предался удовольствию флиртовать под маской, полагая, что нашел именно ту, которую искал» (Фикельмон, 2009: 77). Что до Натальи Викторовны, то «не будучи положительно красивой, она, видимо, нравится больше многих других красавиц. Капризное выражение лица, которое ей очень идет, и особенно красивые глаза - вот в чем ее главная прелесть» (там же: 91). Строганова стала одной из предводительниц дамского эскорта, который повсюду охотился за молодым Николаем I: «Император выглядел как никогда красивым, - сообщала посланница. - Вид завоевателя ему очень подходит, это впечатление усиливает свита прелестных женщин, следующих за ним из залы в залу и ловящих каждый его взгляд. Три главные фигуры в этой группе обожательниц - Наталья Строганова, мадам Завадовская и княжна Урусова» (там же: 99).

Таков результат воспитания в свете. Именно его не хотели для своих супруг те, кто выбирал сам. Отметим внутреннюю неуверенность героев в своей действительной ценности для барышень. Некоторые, как Бенкендорф, выберут красавицу-вдову с двумя детьми - явно пойдет. Другие, как Воронцов, будут рассуждать, что девушкам «может не понравится» седина, возраст, контузии, ранения, «накладные зубы» (в случае С. Г. Волконским) - список можно продолжать. Охоту на себя эти люди не одобряли: она не могла строиться на искреннем чувстве. Самое большое «желать добра».

Случалось, что повидавшие жизнь герои, сами отказывались от совсем молоденьких барышень, понимая свою мнимую привлекательность для них. В 1816 г., мадемуазель Софья Петровна Толстая, московская барышня 16-ти лет, пылко влюбилась в генерал-майора А. Х. Бенкендорфа и хотела выйти за него замуж. «В этом браке меня устраивало все, кроме разницы в годах, - признавался Александр Христофорович, - мне скоро должно было исполниться тридцать, а ей было всего 16 лет; я вскоре должен был покинуть блестящие удовольствия высшего света, а она только входила в него» (Бенкендорф, 2012: 282). Пришлось отговаривать.

На чем строилась подобная неуверенность в себе? На реальной оценке собственных возможностей. Ранения имелись у всех. Случай Милорадовича, который участвовал в 56 сражениях и ни разу не был задет пулей, чтобы пасть жертвой выстрела П. Г. Каховского на Сенатской площади уникален. Легко отделался и А. А. Перовский, которому при Бородино отстрелили палец на левой руке. А вот, побывав в плену, он отморозил ноги и долго ходил на костылях. «Изувечен» - это не только изранен, но и вообще покалечен войной.

А. А. Закревский страдал от трех контузий. Воронцов был ранен в бок под Бородином, и только благодаря ранению выжил - его увезли в тыл. 
Генерал Муравьев сообщал о страшной ране младшего брата, под которым ядром убило лошадь и сорвало мясо с ноги. Он же описал ранения товарищей: «Под Бородином было четыре брата Орловых, все молодцы собой и силачи. Из них Алексей служил тогда ротмистром в конной гвардии, под ним была убита лошадь, и он остался пеший среди неприятельской конницы. Обступившие его четыре польских улана дали ему несколько ран пиками; но он храбро стоял и отбивал удары палашом... Брат его Федор Орлов, служивший в одном из гусарских полков... лишился ноги от неприятельского ядра... Третий брат Орловых, Григорий, числившийся в кавалергардском полку, также лишился ноги от ядра. Я видел, когда его везли. Он сидел на лошади, поддерживаемый подмышки казаками, оторванная нога его ниже колена болталась» (Муравьев, 1989: 112).

В ляжку штыком был ранен «Гергий Мейендорф, прозванный у нас Черным» - частое и типичное ранение для кавалериста, которому пришлось вступить в соприкосновение с вражеской пехотой. Пушечные ядра были опасны не только прямым попаданием. Многочисленные контузии могли аукнуться и страшными мигренями, и глухотой, и полной потерей памяти. «В Смоленском полку служили два сына Алексея Николаевича Оленина, - продолжал Муравьев. - Подняв во время сражения неприятельское ядро, они перекатывали его друг к другу... как вдруг прилетело другое ядро разорвало пополам старшего Оленина, у второго же пролетело ядро между плечом и головою и дало ему такую сильную контузию, что его сперва полагали убитым. Он опомнился, но долго страдал помешательством, отчего он хотя и выздоровел, но остался с слабой памятью и с признаками как бы ослабевших умственных способностей» (там же: 121).

Молодые ветераны страдали от болезней суставов - часто спали на земле, вброд переходили водные преграды, проваливались под лед. Распространено было и общее утомление, буквально валившее с ног. Бенкендорф писал Воронцову летом 1813 г.: «Мое здоровье, расстроенное на протяжении некоторого времени, пришло наконец в такой упадок, что мне стало решительно невозможно продолжать службу; у меня такие боли в груди, что я уже не в силах выносить малейшего движения, мне необходим отдых; к тому же у меня лихорадка и... (отточие в тексте. $-O$. E.), подхваченный в Люнебурге» (Записки Бенкендорфа, 2001: 53).

Следует иметь ввиду, что речь идет об еще молодых людях. Едва отлежавшись, они пускались во все тяжкие. В следующем письме Александр Христофорович каялся перед более сдержанным и благоразумным другом: «Благодаря разным процедурам и лекарствам, мне уже стало много лучше; но надо же было так случиться, чтобы прехорошенькие девицы приехали сюда... и черт меня дернул потратить деньги на их пляски и на то, чтобы себе вредить, прыгая с ними что было мочи: теперь колени у 
меня снова распухли, грудь болит и врач предписывает покой» (Записки Бенкендорфа, 2001: 53).

Двоюродный брат Воронцова - Лев Александрович Нарышкин, когда-то блестящий придворный кавалер и не менее блестящий генерал, так устал, что, по словам знавшего его Ф. Ф. Вигеля, «никуда не ездил и две трети дня проводил в постели», неспособный ни к какой гражданской службе (Вигель, 2003b: 1286).

Болезнями костей и суставов, а также мигренями вследствие контузий страдало множество по возрасту еще далеко не старых офицеров, прошедших войну и заграничные походы. Ведь спать приходилось на земле, и в дождь, и в снег. Яловые сапоги не снимать с ног по несколько месяцев, так что потом они стягивались только вместе с кожей, или под ними открывались цинготные язвы. Переправы через реки наводить вместе с рядовыми, по пояс в воде... (Муравьев, 1989: 150, 151) Понятно, что здоровья это не прибавляло.

Вот как генерал Н. Н. Муравьев описывал отступление от Смоленска: «Брат Михайла сказывал мне, что, возвратившись однажды очень поздно на ночлег и чувствуя лихорадку, он залез в шалаш... и подогретый от озноба скоро уснул». Потом явился хозяин шалаша генерал Д. Д. Курута и выгнал незваного гостя. «Михайла лег больной на дожде, предпочитая умереть, чем проситься на ночлег к человеку, который счел бы сие за величайшую милость» (Муравьев, 1989: 95).

А вот жалоба Ермолова на здоровье. «С тех пор как ты женат, - писал он А. А. Закревскому в 1819 г. - нападаешь на меня, чтобы и я женился также. Между нами в сем случае есть некоторая разница. Мне уже перешло за сорок, ты молод... Жаль мне, что я старею... Ты говоришь о потомстве. До такой степени не простираю я моего самолюбия... Дай Бог свой век прожить порядочно... Было время, что не помышляя о потомстве, имел бы я его... Что бы из меня теперь вышло? ...Итак, друг любезный, прости, что не будет у меня сына» (Давыдов, 2005: 307).

Судьба оказалась милостива, в недалеком будущем у «проконсула» Кавказа появилось четверо сыновей от местных горских женщин. Но сами по себе жалобы и опасения героя показательны. Его корреспонденту Закревскому едва перевалило за тридцать, но после контузии он страдал приступами сильнейших мигреней, и медики не гарантировали долголетия. Они обманулись, Арсений Андреевич умер стариком, занимал высокие должности, но в строй не годился и излечению не подлежал. Великая война переживала и выплюнула калеками тех счастливцев, которых не убила. Пока они носились в полку на жеребце - держались. Но стоило выйти в отставку, глубоко загнанные болезни дали о себе знать.

Перед нами люди, не только «изувеченные», но и полностью изно- 
шенные. В генеральских мундирах при дворе или на балу в Дворянском собрании они еще выглядели «важно», но дома, по удачному выражению А. А. Бестужева-Марлинского, напоминали «завернутый фланелью барометр». Князь Сергей Волконский «страдал невыносимо грудью, а зубы носил накладные, при одном натуральном переднем» (Филин, 2006: 113).

Жена видела в качестве мужа «усталого человека, который по утрам кашляет, целый день зевает и каждый вечер скучает или докучает... Он весь век будто маятник между бутылкой бургунского и склянкой с лекарством» (Бестужев-Марлинский, 1986: 388).

Таких людей следовало «покоить». В прошлом у них могли быть самые яркие амурные похождения, но в браке они ценили отдохновение. В 1825 г. Пушкин отредактировал свои лицейские стихи. Показательно, что «Амур и Гименей» претерпел только лексические, но не смысловые изменения. Также, как в годы юношества, когда любая замужняя красавица казалась законной добычей, уже зрелый поэт в момент написания ядра романа именовал греческое божество брака: «молчаливый, холодный, дряхлый и ленивый». Гименею противопоставлен Амур или Эрот, которого ведет «дурачество» или «безумие» (Тынянов, 2001: 135).

«Хорошо еще, если он не отправится тратить случайную искру веселости и здоровья с какой-нибудь актрисой, - продолжал Марлинский. ...Жена поневоле станет бегать из дома. Глядь, молодежь увивается возле нее, словно хмель, и вот какой-нибудь краснощекий франтик приглянулся ей более других. Рассыпается он в объяснениях мелким бесом... Она, разумеется, ничему этому не верит, но, с должным для чиновной дамы приличием, с ноги на ногу идет навстречу к обману для того, чтоб при случае броситься в кресло, закрыть платком глаза и сказать: “вы, сударь, камень, вы, сударь, лед, вы злодей, вы меня обольстили”» (Бестужев-Марлинский, 1986: 388-389).

Именно такого будущего и хотели избежать для себя и своих жен «молодые генералы», отказываясь брать в супруги слишком молоденьких барышень. Возвращаясь к вопросу о ранах, сообщим, что многие из тех, кто пережил сражения, уже после войны умерли сравнительно молодыми. Поэт С. Н. Марин - друг Воронцова, Бенкендорфа и Закревского - скончался в 1813 г. от пули, полученной еще при Аустерлице, она осталась в ране и двигалась вместе с кровью по телу, пока не достиг сердца. И. С. Леонтьев в 1824 г., Н. М. Сипягин ушел из жизни в 1828 г., Я. А. Потемкин в 1831 г.

Поговорим о живых. Чем они располагали в имущественном отношении? К 1820-м гг. дворянские состоянии серьезно поистощились. Сыграли роль и многодетность, и тяжелая война. Будущее также не обещало приятных сюрпризов: падали цены на сельскохозяйственные продукты, крестьяне нищали. Помещики отчаивались получить с них денежный об- 
рок. Женитьба же - дорогое удовольствие.

Прежде вполне «достаточные», как тогда говорили, роды теперь надеялись на сочетание жалования и доходов с имений. Без помощи казны, личных пожалований государя, трудно было выучить детей, определить их на хорошее место, а подчас и свести концы с концами.

При этом война выдвинула на первые места в военной администрации немало толковых командиров - со звездами и блестящими перспективами, но без гроша. Не даром острая на язык горничная Лиза из «Горя от ума» замечает барышне:

«Как все московские, ваш батюшка таков:

Желал бы зятя он с звездами да с чинами,

А при звездах не все богаты, между нами».

В прежние - Екатерининские времена - к ордену часто прилагалось существенное денежное или земельное пожалование. Прося для Ф.Ф.Ушкова, за которым числилось всего 30 душ в Пошехонье, «душ 500 хорошенькую деревеньку», Г. А. Потемкин писал императрице: «Тогда он будет кавалер с хлебом» (РГАДА. Ф.1. Оп. 1/1. №43. Л. 56). Сразу вспоминается шутка Н. Н. Ермолова об одном из сослуживцев, уволенном в отставку «с мундиром, но без штанов» (Русский литературный анекдот, 1990: 101). Уволить с правом ношения формы считалось весьма почетно, но что толку во внешних знаках отличия, когда не на что жить?

При Александре I практика раздачи земель и денег почти прекратилась, что объясняли и скуповатостью государя, и дефицитом казны. А служить, как тогда говорили, «из чести», могли немногие. Ведь и амуницию, и пропитание офицер даже в военное время должен был приобретать сам. Не имея возможности рассчитывать на щедроты из августейших рук, некоторые поправляли дело удачной женитьбой. Ведь чин кое-чего стоил: обеспечивал возможность являться при дворе, определял место по отношению к государю на официальных церемониях, длину шлейфа у жены, право ехать на почтовых лошадях без очереди, есть на серебре, а не на фарфоре и т. д. Для дворянства со времен Петра I и особенно в екатерининскую эпоху был разработан и утвердился целый список поощрений, заставлявший считать службу почетным и престижным делом. Поэтому представители состоятельных семей, чьи отпрыски не отличились на полях сражений, случалось, выдавали дочерей за выдвиженцев «горячего времени».

Так, Арсений Андреевич Закревский, небогатый помещик из захолустья, быстро поднялся в годы Наполеоновских войн, исключительно благодаря собственным дарованиям. В январе 1812 г. он был назначен директором Особенной канцелярии при военном министре - главной военной разведки, а в 1815 г. занял место дежурного генерала Главного штаба (фактически заместителя начальника этого учреждения), в формировании ко- 
торого сыграл важную роль (Давыдов, 2005: 23). В 1818 г. Закревский, тогда еще обласканный милостью царя, женился на Аграфене Толстой, взяв за нее в приданое 12 тыс. душ. Представители старинной знати Толстые уступили только потому, что сватом выступил сам Александр I.

В «Войне и мире» воспитанник Ростовых Борис Друбецкой, представитель древнего, но обедневшего рода, сделав штабную, адъютантскую карьеру, женится на богатой невесте Жюли Карагиной. Приданое тяготело к чину, а чин искал приданого.

Однако не всем везло. Алексей Петрович Ермолов, например, уже став командующим Кавказским корпусом, не получил от государя никаких пожалований и оставался беден. Поэтому ему пришлось отказаться от перспективы создать семью с женщиной своего круга - ее следовало содержать подобающим образом - и ограничился походными женами из местных горских племен. В письме к Закревскому он с грустью рассуждал о любви своей молодости: «Было время... весьма был близок от женитьбы, но скудное состояние с моей стороны и ее бедность не допустили меня затмиться страстью... Я, как и ты, имею правило ничего не просить, а дать мне, быть может, не догадались бы» (Сборник Русского ..., 1890: 355).

Если мужчина-дворянин рассчитывал содержать семью, ему следовало не просто служить, а служить успешно, нацелясь на высокий чин и хорошее приданое невесты. Кроме того, жены играли немалую роль в продвижении по службе. Высокой должности не добиться, сидя в деревне. Связи, покровительство, нужные знакомства - все в Петербурге или Москве. И чтобы получить искомое место, надо вращаться, бывать на балах и принуждать мужа танцевать у нужных людей, разъезжать по столицам и одним дамам известным образом устраивать карьеру мужа. У Толстого «маленькая княгиня», жена Андрея, тоже старается продвинуть мужаадъютанта во флигель-адъютанты, используя чисто-дамские методы разговоры с Анной Павловной Шерер и поиск покровительства. Все это претит герою, который рвется за славой на войну, в то время как супруга стремится удержать его в Петербурге и выгоднейшим образом пристроить к должности.

Выдвижение мужей и любовников посредством женских связей, особенно придворных, ведших к самой влиятельной даме России - вдовствующей императрице Марии Федоровне - воспринималось мужским сообществом весьма болезненно. Как унижение. В донесении управляющего III Отделением М. Я. Фон Фока, чиновника умного, образованного и весьма чувствительного к колебаниям общественного мнения, сказано, что «возвышением Грибоедова на степень посланника» «раскрыта важная истина, что человек с дарованиями может всего надеяться от престола, без покровительства баб» (Из донесений ..., 2001: 333-334). 
Тем не менее, значительному числу тогдашних военных выдвиженцев густые эполеты на плечи надели именно царица-вдова и окружавшие ее дамы по неумолчным просьбам жен, матерей и сестер.

Создавая карьеру супругов, женщины удовлетворяли, в первую очередь, собственное тщеславие. Честолюбие обоих полов - одно из самых развитых чувств в описываемую эпоху. В черновике «Романа в письмах» Пушкин заметил: «Мужчины почти не знают любви: они развлечены честолюбием». И далее: «...Многие приняли сторону дам большого света, утверждали, что любовь питается блеском и тщеславием» (Пушкин, 1962а: 587).

Правительство и сразу после войны 1812 г. и полутора десятилетиями позднее было заинтересовано в выходе вчерашних военных чинов в отставку, но не для того, чтобы они поселились в родовых деревнях, а для того, чтобы заняли высокие должности в гражданской администрации. Образование большей части офицеров это позволяло.

Не стоит забывать, что речь идет, главным образом, о детях вчерашних екатерининских «служивцев», которые в течение всей жизни снопами вязали лавры в войнах с Турцией, Швецией и Польшей. А вот образование у отцов было весьма скромным. Детей же они хотели видеть людьми просвещенными и готовили их, судя по всему, для жизни в мирное время - ведь они сами уже всех победили! Кто же знал, что судьбы мира сложатся иначе.

После домашнего обучения для него могли последовать другие учебные заведения. Пажеский корпус, или пансион аббата Николая, чрезвычайно популярный у петербургской аристократии на рубеже веков - его заканчивали А. Х. Бенкендорф, М. Ф. Орлов, С. Г. Волконский и множество других ярких деятелей эпохи. Возможна была Школа Колонновожатых, с которой связаны имена Муравьевых и Чернышевых. Курс в Петербургском или Московском университетах. Учеба обычно бывала грубо прервана войной, и после победы к ней практически никто не возвращался.

Так, Василий Алексеевич Перовский, будущий знаменитый оренбургский генерал-губернатор и исследователь Аральского моря, побочный сын графа А. К. Разумовского, родился в 1795 г. и, по разным данным закончил либо юридический факультет Московского университета, или Школу Колонновожатых. С началом войны вступил в лейб-гвардию, при Бородине был адъютантом у Милорадовича, побывал во французском плену, бежал. Командовал эскадроном гусарского полка, был взят адъютантом в свиту императора, сражался при Люцене, Бауцене, Кульме, Лейпциге и Париже. После войны стал адъютантом великого князя Николая, который к нему очень благоволил. Один из его университетских однокашников, будущий сенатор К. И. Фишер описал подобный тип людей: «Хорошо начитанный он в совершенстве знал французский и немецкий языки, любил музыку... По складу ума человек либеральный, был горд и обидчив. Рыцарь без 
страха и упрека, с аристократическим лицом. С великим князем Николаем Павловичем он общался свободно, даже слишком» (Бандурин, Португальский, 2006: 145-146). Хорошее образование, опыт войны, воспитывавший независимость, либеральная складка во многом замешанная на аристократизме, и давали таким людям внутреннее право на «излишнюю свободу» в обращении с августейшими лицами.

Именно после полосы Наполеоновских войн наши герои и реализовывали сугубо гражданскую часть своего образования. В целом ряде случаев им приходилось подменять местную администрацию. Последняя за долгие годы войн была из рук вон плоха. Но ее до поры, до времени не трогали.

Место квартального надзирателя, например, приносило ежегодно, помимо скромного жалования, более 3 тыс. рублей дохода. «Все полицейские офицеры... в особенности квартальные надзиратели могут каждый день варить себе суп из курицы, - писал управляющий III отделения М.Я.Фон Фок уехавшему в Москву на коронационные торжества Бенкендорфу, - ... не притесняя никого, иметь ежедневный доход по 50 рублей; самый бедный квартал дает надзирателю до 3. 000 рублей в год. Поэтомуто квартальные надзиратели прямо заинтересованы в беспрекословном исполнении приказаний своего начальства, которое имеет право карать тотчас, ничем не оформляя своих действий, т. е. без всякого следствия» (Фок, 2002: 70).

Максимум, на что могло надеяться правительство «в благоустроенном государстве» - чтобы брали «по чину». Эту тонкую грань современному исследователю нащупать очень трудно, а вот люди того времени интуитивно чувствовали: сколько можно, а сколько - сверх меры. Когда в 1817 г. Бенкендорф ревизовал воронежских чиновников, бравших взятки в размере годового жалования, казенные крестьяне доносили, что к Рождеству и Пасхе с них собирают «христославное» в размере «видимоневидимо» - ветчины, поросят, яиц, масла и птицы, отчего они уже «стали хуже нищих» (Олейников, 2009: 175). Такое положение грозило разорить налогоплательщиков и вызвать их волнения, чего старались избежать.

Присловье: «Воруй, да не заворовывайся», - могло бы стать их девизом. Мера находилась где-то между собственным благополучием и запретом разорять тех, на ком благополучие держится. Но уже к началу николаевского царствования баланс был нарушен: коррупция приобрела эпические размеры. Для того, чтобы ревизовать чиновников той или иной губернии, назначались лица, располагавшие независимым воинским контингентом - командиры бригад и дивизий, дислоцировавшихся неподалеку. Вспоминаются слова Бенкендорфа в письме М. С. Воронцову: «Наших чиновников не деморализуешь ни артиллерией, ни пехотой».

Вот как картина выглядела глазами английского резидента при рус- 
ской армии в 1829 г. «В царствование покойного императора, - писал капитан Джеймс Александер о временах Александра I, - в государственных учреждениях процветала система взяток, хотя царь... и старался их контролировать. При восшествии на престол нынешний энергичный император высказал намерение покончить со взяточничеством в учреждениях. Чиновников, уличенных в лихоимстве, он приказал штрафовать, сажать в тюрьмы, отправлять в ссылку. Это продолжалось некоторое время, но вскоре выяснилось, что все дела остановились: чиновники не проявляют должного усердия, таможня не пропускает корабли, во всех департаментах воцарились проволочки и просрочки до поры, пока все не вернулось на круги своя» (Александер, 2008: 81-82).

Воровать следовало «по маленькой», особо не обижая просителей. Такой взгляд восходил еще к практике XVII в., когда воевода получал территориальную единицу не только в управление, но и в «кормление» лично себе и своему штату.

Показательно отношение к генерал-губернаторам. Пока налоги взимались, а население не роптало, на их «грехи» смотрели сквозь пальцы. Когда министр внутренних дел А. А. Перовский решил направить в Первопрестольную ревизора, император остановил его словами: «Я уже просил не трогать ни Голицына в Москве, ни Воронцова в Одессе» (Бутурлин, 1897: 340). Оба пользовались огромным влиянием среди петербургских чиновников и любовью местных жителей, оба как нельзя лучше подходили для своих мест. Граф М. С. Воронцов, воспитанный в Англии, склонный покровительствовать коммерции (вспомним пушкинское «полукупец»), великолепно ладил с разноязыким населением юга России, которое главным мерилом жизненного успеха избрало обогащение. Князь Д. В. Голицын, коренной москвич и представитель древней аристократии, удовлетворял гордые семьи, жившие в Первопрестольной. Ему они соглашались подчиняться без «порухи» родовой чести, и генерал-губернатор действительно много сделал для благоустройства города.

Но случаев взяток и злоупотреблений по всей России были не десятки, а сотни и тысячи. В 1826 г. Управляющий III отделением М. Я. Фок доносил из Петербурга уехавшему в Москву Бенкендорфу: «Теперь слышится со всех сторон: “Пора положить преграду грабежу и наказать взяточников”... Доносы посыпятся градом... В продолжение двадцати пяти лет бюрократия питалась лихоимством, совершаемым с бесстыдством и безнаказанностью... Ремесло грабителя сделалось уж слишком выгодным. Комиссионеры (чиновники, берущие комиссию, взяточники. - О. Е.) на все решались, все делали, ни в чем себе не отказывали; все их счеты принимались, и авторитет общества не восставал против них... Правительству предстоит выбрать одно из двух: или допустить ужасное зло, или 
прибегнуть к реформе... и найти в этом средство к исправлению старых несправедливостей» (Фок, 2002: 80-81).

Уточнение «за последние двадцать пять лет» - вовсе не случайно. Оно как бы охватывало царствование Александра I, но острие критики направлено не в него. Каждый знал: за войну чиновники распоясались стали брать «не по поступкам». А «война» для людей того времени охватывала не только грозный 1812 г. и Заграничный поход русской армии. Противостояние с революционной Францией началось в конце XVIII в., продолжалась в антинаполеоновских коалициях и, едва завершившись с выводом русских оккупационных корпусов из-за границы, вновь дало о себе знать полосой европейских революций 1820-х гг. Почти четверть века внимание правительства было приковано к внешней политике. Чтобы действовать без помех, требовался внутренний мир - чиновников старались не трогать, не злить частыми проверками, не подвешивать над их головами Дамоклов меч. Результатом стало ощущение «безнаказанности», о котором писал фон Фок.

Попытки ревизовать отдельные случаи «злоупотреблений» лишь оттеняли общую безрадостную картину. Так, в 1816 г. Александр I приказал И. Ф. Паскевичу, командовавшему дивизией в Смоленске, расследовать т. н. Липецкое дело. Казенные крестьяне, проживавшие под Липецком и разоренные Наполеоном, получили безвозмездно хлеба на 21 тыс. рублей и освобождение от недоимок на 60 тыс. рублей. Однако они взбунтовались, отказавшись платить налоги за 1814 г. и говоря, что на самом деле с них взыскали подати в полном объеме, не выдали зерна да еще и продали весь хлеб на корню откупщикам. За неуплату обвиняемые были приговорены к сечению плетьми. Особенно Паскевича возмутил тот факт, что среди наказанных оказались два 80-летних старика. Ни Уголовная палата Смоленска, ни Сенат не нашли в действиях местных чиновников состава преступления. Расследование выявило, что многие крестьяне оказались в тюрьме даже без допроса, только по показаниям местных властей. При этом хитрецы «приказные» везде соблюли букву закона, а неграмотные люди оказались обобраны и взяты под стражу. На имя императора Паскевич писал: «Может быть, бессовестные деяния удельных чиновников облечены формой закона, но по совести они преступны и всякому беспорядку они настоящая причина» (цит. по: Бантыш-Каменский, 1840: 207). По его ходатайству обвиняемые были освобождены и все-таки получили денежное пособие, а также рассрочку выплаты оброка.

Следует отметить, что и Паскевич, и Бенкендорф, ревизуя лихоимства местных властей, находились в подвешенном состоянии - оба намеревались жениться, для чего командирам их уровня требовалось разрешение императора. Сразу же после проведенных расследований такие разреше- 
ния были получены, и в 1817 г., бывшие следователи обзавелись семьями. Так, Александр I обеспечил лояльность проверяющих и их честность. Однако подобный способ ревизии не свидетельствовал в пользу управляемости страны. Скорее он говорил об известной беспомощности верховной власти. «Некем взять» относилось не только к крестьянскому вопросу.

Нельзя сказать, чтобы бюрократический аппарат выразил восторг по поводу широкого назначения на гражданские должности вчерашних офицеров. В этом смысле показательна позиция Ф. Ф. Вигеля, в тот момент градоначальника Керчи. Сам гражданский чиновник, он не терпел вмешательства офицеров в систему управления. Не поладил с генералгубернатором Одессы М. С. Воронцовым, сетуя, что из его канцелярии, где засели бывшие штабные русского Оккупационного корпуса в Мобеже, «решения вылетают с такой же скоростью, с которой туда влетают прошения», а сами новоявленные канцеляристы «не могут отличить докладной записки от рапортички». Мало ли что население довольно - делопроизводственный порядок «страждет» (Вигель, 2003b: 1210).

Еще более любопытна позиция либерального цензора А. В. Никитенко, который видел в чиновничьей коррумпированности форму борьбы с самодержавием. В мае 1843 г. он писал: «Важную роль в русской жизни играют государственное воровство и так называемые злоупотребления: это наша оппозиция наш протест против неограниченного самовластия. Власть думает, что для нее нет невозможного, что ее воля нигде не встречает сопротивления; между тем, ни одно ее предписание не исполняется так, как она хочет. Исполнители притворяются в раболепной готовности все сделать, что от них потребуют, а на самом деле ничего не делают так, как от них требуют» (Чукарев, 2005: 443).

Тем не менее, что-то приходилось делать. И один из путей сокращения мошенничества правительство видело именно в пересаживании вчерашних военных на гражданские должности. Что это давало нашим героям? В первую очередь, удаление из среды потенциальных заговорщиков и неучастие в организациях декабристов. А в перспективе - чистоту репутации и возможность найти хорошую должность при новом монархе Николае I.

Что ждало таких людей за порогом армейской службы? После возвращения из Заграничного похода? Возможны варианты. Кто-то стоял в оккупационных корпусах во Франции или в Саксонии, как М. С. Воронцов и Репнин, брат Волконского. Кто-то отправился в дальний гарнизон, как А. Х. Бенкендорф. Кто-то во Вторую армию в Тульчин, как М. Ф. Орлов и позднее П. С. Киселев. Кто-то на Кавказ, как А. П. Ермолов. Кто-то, помучившись вдали от столицы, был, наконец прикомандирован в качестве чиновной и очень уважаемой няньки к великим князьям, как И. Ф. Паскевич, которого Николай I всю жизнь называл «отец-командир». Кто-то 
очутился у кормила Главного штаба, как П. М. Волконский и А. А. Закревский. Кто-то командовал гвардейским корпусом, как В. В. Васильчиков и его штабом, как Н. М. Сипягин. Кто-то очутился во главе одного из лучших полков, как Я. А. Потемкин или даже целой кавалергардской бригады, как А. Ф. Орлов.

В первую секунду все было хорошо. Люди наслаждались миром, отдыхом и отсутствием требования немедленно вставать, идти незнамо куда, чтобы там умереть. Нравы царили самые либеральные. Их в стихотворении, посвященном Семеноскому полку, нарисовал будущий декабрист полковник Ф. Н. Глинка, адъютант Милорадовича и редактор «Военного журнала»:

«Была прекрасная пора:

Россия в лаврах, под венками,

Неся с победными полками

В душе - покой, в устах - «ура!»,

Пришла домой и отдохнула.

Минута чудная мелькнула

Тогда для города Петра.

Окончив полевые драки,

Носили офицеры фраки,

И всякий был и добр, и свеж,

Пристрастье к форме пригасало,

О палке и вестей не стало,

Дремал парад, пустел манеж».

Ту же картину рисует другой декабрист Н. И. Лорер: «Тогда Гвардейский корпус был во всем своем блеске. Полки, наполняемые молодежью, по возвращении своем из Парижа, видели в рядах своих новое поколение офицеров, которое... стало понимать, что не для того только носят мундир, чтобы обучать солдат маршировать да выправке. Все стали стремиться к чему-то высшему, достойному, благородному. Молодежь много читала, стали в полках заводить библиотеки... Я тогда много знал образованных людей между офицерами... Служба мирного времени шла своим чередом, без излишнего педантизма, но, к сожалению, этот порядок вещей скоро стал изменяться» (Лорер, 1984: 56).

Сгустились тучи. Император считал, что лучшим способом восстановить порядок, нарушенный войной, вернуть подчиненность и поставить на место офицеров, которым «вскружили голову победы», является плацевая строевая подготовка. Нельзя отрицать ее воздействие на умы: когда человек много часов выполняет изнуряющие упражнения, реагируя только на окрики команд и звуковые сигналы труб и барабанов, а сам безгласен, он чувствует себя подавленным и готовым подчиняться. 
Паскевич вспоминал: «После 1815 года фельдмаршал Барклай-деТолли, который знал войну, подчиняясь требованиям Аракчеева, стал требовать красоту фронта, доходящую до акробатства, преследовал старых солдат и офицеров, которые к сему способны не были, забыв, что они недавно оказывали чудеса храбрости, спасли и возвеличили Россию... наши георгиевские кресты пошли в отставку... Что сказать нам, генералам дивизий, когда фельдмаршал свою высокую фигуру нагибает до земли, чтобы ровнять носки гренадеров? ...В год времени войну забыли, как будто ее никогда не было, и военные качества заменились экзерцирмейстерской ловкостью... Не раз, возвращаясь с плаца, мне приходило желание все бросить и в отставке предаться семейной жизни» (Брюханов, 2004: 76).

Знаменательная мысль. Среди наших знакомых - как независимых упрямцев, так и тех, кто предпочел бы лучше подчиниться, нем нажить неприятности - не было такого, кто не сетовал бы на плац. И кто не задумывался бы о жизни на свободе и в покое. Письма офицеров той поры - это плач в голос, а иногда и крик. Денис Давыдов назвал аксельбанты «наплечными кандалами». Ермолов, как огня, боялся назначения в гренадерский корпус и мечтал об отъезде на Кавказ: «Во сне грезится та сторона и все желания умерли», а когда вспоминал столичные плацы, страх «задирал» его «по спине» (Сборник Русского ..., 1890: 193). Он, как другой герой, Граббе, мог сказать о себе императору: «Я войной испорчен для парадов».

Фактически так думал каждый. У хороших, попечительных, нужных армии командиров создавалось впечатление, что, чем больше они выбиваются из сил, тем холоднее и неприветливее к ним относятся. Получив отказ в очередной просьбе, Воронцов писал из Мобежа старинному другу генералу Сабанееву: «Что за манер, что о вещи, не стоящей другого предмета, кроме пользы службы, надо просить мне, как о партикулярной себе милости и всегда ждать отказа? Кому нужнее, чтобы 12-я дивизия всегда была хороша и поддерживала славу оружия нашего? Ведь не мне столько, не графу Воронцову, который может быть переведен и в другую дивизии и куда угодно, и может дома жить спокойно и благополучно. Армии это нужно, Александру Павловичу, и отечеству нашему, России. Не мне даются отказы, я ведь не для себя прошу, а для Службы» (там же: 263).

Послушаем и другую сторону. Александр I возложил неблагодарный труд подтягивать полки по строевой линии на младших братьев Николая и Михаила. Совсем юных, которых воевавшие подчиненные не боялись и не слушались. Исполнение его поручений сильно испортило им репутацию, тем более что за дело они принялись с рвением. Такое распределение ролей позволяло императору самому не ссориться с офицерским корпусом. А об угрозе со стороны братьев не беспокоиться - они стали непопулярны. Николай I писал о тогдашнем положении вещей: «Оставлен я был 
один с пламенным усердием, но с совершенною неопытностью... Служба шла везде совершенно иначе, чем слышал волю моего Государя, чем сам полагал, разумел ее, ибо правила оной были твердо в нас влиты. Я начал взыскивать, но взыскивал один, ибо что я по долгу совести порочил, дозволялось везде даже моими начальниками... Было время (поверит ли кто сему), что офицеры езжали на учения во фраках, накинув шинель и надев форменную шляпу. Подчиненность исчезла и сохранялась только во фронте» (Николай I, 2002: 87).

Обратим внимание, во-первых, на фрак.Для наших героев был привычнее мундир - облекаясь им, офицер как бы облекался репутацией целого полка и не мог манкировать честью. Партикулярное платье подразумевало свободу не только от «подчиненности», но и во многом и от требований присяги, которые стали рассматриваться как слишком тяжелые.

Второе, что следует отметить, это сохранение служебной иерархии только в строю. Выпорхнув из него в светскую гостиную, на бал или в театр, дворянин чувствовал себя равным среди равных. Генералы 1780-х гг. рождения были склонны поощрять молодежь, поскольку и сами исповедовали либеральные идеи. Но юношам не свойственно чувство меры. Панибратство, как в случае с Орловым, могло обернуться жестоким оскорблением. Когда разразилась т. н. Семеновская история, Закревский писал, что прежний командир полка Потемкин: «неосновательно и излишнею своею деликатностью приучил подчиненных ему офицеров не полагать никакого различия между чинами и вне фрунта не оказывать ни малейшего уважения к старшим своим и даже к нему самому» (Олейников, 2009: 185).

Этот дух дружества очень импонировал молодому Пушкину, он любил единый круг товарищей, не разделенных званиями, шумную беседу нараспашку, застолья, где блюда не носят по чинам. Встретивший поэта за столом у Воронцова в Одессе полковник И. П. Липранди, старый кишиневский приятель, отмечал раздражение и недовольство Александра Сергеевича, хотя он через стол переговаривался с дамами - графинями Нарышкиной и Воронцовой. «Пушкин был чрезвычайно сдержан и в мрачном расположении духа», а встав из-за стола, бросил полковнику: «Это не обеды Благовского, Орлова и даже...» - не окончил фразы и вышел (Липранди, 2005: 309).

Между тем, открытые столы начальники держали специально для своих подчиненных не только чтобы материально облегчить их жизнь. Совместное застолье у генерал-губернатора воспитывало в чиновной, как и в полковой среде дух корпорации, сплоченности и преданности начальнику. Посетивший Францию в 1816 г. Ф. Ф. Вигель нарисовал картинку, которую позднее не раз наблюдал и в Одессе: «Мобеж был полон его (Воронцова. - O. E.) именем, оно произносилось на каждом шагу и через 
каждые пять минут... Он имел непогрешимость папы; он не мог сделать ничего несправедливого или неискусного; ничего сказать неуместного; беспрестанно грешили они против заповеди, которая говорит: не сотвори себе кумира. Не быв царем, вечно слышал он около себя лесть, только чистосердечную, энтузиазмом к нему произведенную» (Вигель, 2003a: 907).

Неудивительно, что молодой поэт был раздражен. Со свой стороны Воронцов не совершал ошибок Орлова, не шел на излишнее сближение. Он частным образом признавал, что терпеть не может таких характеров, как у Пушкина и Байрона, нарушителей общественного спокойствия, от поведения которых окружающим становится стыдно. То есть ждал скандала. «Не странно ли, что я поладил с Инзовым (губернатором Кишинева. - О. Е.), а не мог ужиться с Воронцовым, - писал поэт А. И. Тургеневу в июле 1824 г. ...Старичок Инзов сажал меня под арест, всякий раз как мне случалось побить молдавского боярина. Правда - но зато добрый мистик в то же время приходил меня навещать и беседовал со мной о гишпанской революции. Не знаю Воронцов посадил ли бы меня под арест, но уж, верно, не пришел бы ко мне толковать о конституции Кортесов» (Пушкин, 1962b: 106).

Однако стена холодности не спасла Михаила Семеновича: он получил эпиграмму еще более обидную, чем Орлов, став для поколений читателей не героем, не спасителем нескольких сотен раненых товарищей из горящей Москвы, не командующим Оккупационного корпуса, оплатившим все долги своих подчиненных, не благодетелем Юга России, а «полуподлецом». Говорят, Пушкин позднее сожалел...

Вернемся к рассказу молодого Николая Павловича: «По мере того, как я начинал знакомиться со своими подчиненными... я возымел мысль, что под сим, т. е. военным распутством, кроется что-то важное... Вскоре заметил я, что офицеры делились на три разбора: на искренно усердных и знающих; на добрых малых, но запущенных и оттого незнающих, и на решительно дурных, т. е. говорунов дерзких... Сии-то люди составляли как бы цепь через все полки и в обществе имели покровителей, коих сильное влияние оказывалось всякий раз теми нелепыми слухами и теми неприятностями, которыми удаление из полков мне оплачивалось» (Николай I, 2002: 88).

Когда Бенкендорф стал начальником штаба Гвардейского корпуса, он не сразу осознал, что есть люди, которых он не может одернуть в строю или посадить на гауптвахту в силу их высокого происхождения, родства и связей. В первое время за его промашки ездил извиняться по великосветским гостиным командир корпуса генерал Васильчиков (Олейников, 2009: 183).

Восстание Семеновского полка в октябре 1820 г. стало рубежным моментом. Кто-то из офицеров спохватился. Кто-то решил идти дальше. «Розовый цвет либерализма стал... переходить в кроваво-красный», - писал Вигель (Вигель, 2003a: 247). 
Вспомним похвальное слово Семеновскому полку, сочиненное Глинкой:

«Зато солдат, опрятный, ловкий,

Всегда учтив и сановит,

Уж принял светские уловки

И нравов европейский вид...

Но перед всеми отличался

Семеновский прекрасный полк,

И кто ж тогда не восхищался,

Хваля и ум его, и толк,

Ичеловечные манеры?»

Эти-то «человечные манеры» оказались не ко двору. На смену либерального Потемкина пришел не просто требовательный, а жестокий подполковник Ф. Е. Шварц, выпорхнувший из-под крыла А. А. Аракчеева. Его при всем желании невозможно было уважать, а требовалось подчиняться. Объясняя начальнику Главного штаба произошедшее Бенкендорф писал: «Офицеры, оскорбленные именем, манерами, репутацией человека, совершенно чуждого полку, восстали против назначения, казавшегося им оскорбительным... Не будучи в состоянии приобрести уважение, Шварц решил заставить себя бояться, и в этих видах он стал употреблять наказания скорее позорные, чем строгие; подробности их отвратительны (однажды, например, он вырвал солдату ус. - O. E.); генерал Васильчиков неоднократно ему выговаривал. Пусть сопоставят то сознание своего достоинства, которое отличало полк более сотни лет, с обращением, коему он подвергся в продолжение последнего года, и тогда будет нетрудно понять, что подобное положение должно было разрешиться кризисом» (Олейников, 2009: 186).

Осенью доведенный до отчаяния придирками Шварца полк попытался подать на высочайшее имя петицию, собрался и отказывался расходиться. Сначала вся 1-я «государева рота» строем отправилась в Петропавловскую крепость, на следующий день «мятежный» полк был окружен частями Гвардейской пехоты и отправлен в крепость, откуда в Кексгольм и Свеаборг. Полк был раскассирован, а на его месте создан новый из армейских частей.

Семеновская история была не просто скандалом. А скандалищем. Она наглядно показывала уехавшему на конгресс в Тропау Александру I, что он не может положиться на старых офицеров, занимавших в гвардии лучшие должности. Их снизу подпирали аракчеевские креатуры, такие, как Шварц. Нельзя исключить, что вся интрига была спланирована временщиком, как звено в затяжном противостоянии, которое он вел с Главным штабом. 
Вокруг Главного штаба, которым руководил князь Петр Михайлович Волконский, друг детства Александра I, (прообраз князя Андрея на Аустерлицком поле - тоже ранен и тоже со знаменем в руках) скапливались заслуженные офицеры с хорошо известными в армейской среде именами. Закревский, Ермолов, Воронцов, Киселев и десятки других, где бы они ни служили, но тяготели именно к Главному штабу, где их старались прикрывать и продвигать.

Отличительной чертой этого круга стало неприятие военных поселений. Последние считались детищем Аракчеева. Хотя идея принадлежала императору, но воплощение ее в жизнь, часто крайне жестокими методами, было возложено на графа «Силу Андреевича». Последний, также по желанию государя, выдвигал из «вышколенной» среды поселенческих офицеров новые кадры для армии и гвардии. Шварц был любимцем Аракчеева, и не смотря на то, что руководство Гвардейского корпуса не раз ставило ему на вид излишне суровое обращение с подчиненными, продолжал демонстративно насаждать в гвардейском полку «поселенческие» порядки - поднимал руку на солдат, грубо разговаривал с офицерами. Шварц явно чувствовал за своей спиной поддержку. Семеновцев точно провоцировали на неподчинение.

Мятеж в гвардейском полку оказался крайне выгоден именно окружению Аракчеева. С важнейших постов были сняты и переведены на менее значимые должности его неприятели. Волконскому и Закревскому пришлось покинуть Главный штаб, Васильчиков больше не командовал гвардией, а Бенкендорф, оказавшийся между двумя враждующими партиями, как между молотом и наковальней - штабом Гвардейского корпуса. На их места Аракчеев выдвинул свои креатуры. Вероятно, тогда лишился хорошей должности и будущий муж Татьяны.

Характерно, что молодой Николай, так ратовавший за наведение порядка в гвардии, Аракчеева не терпел, считал душегубцем и, вступив на престол, отправил в отставку. А вот к тем командирам, кто пострадал после Семеновской истории, скорее благоволил. Он не считал их виновными, потому что лично они ничего не могли изменить: «Корпусом начальствовал тогда генерал-адъютант Васильчиков; к нему я прибег... часто изъяснял ему свое затруднение, он входил в мое положение, во многом соглашался и советами исправлял мои понятия. Но сего не доставало, чтобы поправить дело; даже решительно сказать можно - не зависело более от генерал-адъютанта Васильчикова исправить порядок службы, распущенный, испорченный до невероятности с самого 1814 года, когда, по возвращении из Франции, гвардия осталась... под начальством графа Милорадовича» (Николай I, 2002: 87-88).

Выходило так, словно Александр I хотел сначала распустить гвардию, 
выявив наиболее ретивых, а потом очиститься от них. Под железную метлу попали порядочные, знающие офицеры. Позднее Николай I благоволил Волконскому и Закревскому, Васильчиков получил право входить к императору без доклада, Бенкендорф, помимо прочего, стал личным другом. Значит, далеко не все решала плацевая годность. Не привычно, но факт: если Александр I в последние годы царствования насаждал Шварцев, то его брат тяготел к противоположной когорте.

Чтобы привести гвардию в чувства, император приказал в марте 1821 г. вывести ее из столицы и совершить поход по западным губерниям. Это была тренировка вдали от развращающей столичной жизни. В сентябре на смотре в Бешенковичах гвардия была как бы прощена, Александр I пожаловал много наград, но прежних должностей провинившимся командирам не вернул. Зиму 1821-1822 гг. Гвардейский корпус оставался в литовской глуши и только летом присмиревшие полки вернулись в Петербург.

Был еще один эпизод, серьезно повлиявший на офицерскую жизнь рубежа 1820-х гг. - это знаменитое письмо начальника библиотеки штаба Гвардейского корпуса и правителя Канцелярии комитета о раненых М. К. Грибовского - члена Коренной управы Союза благоденствия. В Записке последний извещал правительство о существовании среди гвардейцев тайного общества, той самой «цепи через все полки», о которой стал догадываться великий князь Николай. Откровения Грибовского долго придерживались вышестоящими начальниками, в том числе и Васильчиковым, из опасения вызвать на свою голову гонения - де, допустили. Уже после Семеновской истории Бенкендорф помог Грибовскому подать донесение на высочайшее имя. Позднее Александр Христофорович сетовал, что, если бы тогда же были приняты надлежащие меры, восстания на Сенатской площади не последовало - заговор удалось бы пресечь на корню, еще в 1821 г. (Олейников, 2009: 192-195). Однако Александру I сие было неугодно.

Но шуму донесение наделало. Заговорщики узнали, что об их существовании известно правительству. В Москве в январе 1821 г. собрался съезд Союза благоденствия, который распустил организацию, дабы избавиться от ненадежных членов. Ведь общее недовольство вовсе не означало готовности к решительным революционным действиям. Например, послушав на съезде Михаила Орлова, который впервые в истории русских революционных обществ предложил для пополнения денежных средств не продавать драгоценности жен, а устраивать разбойничьи налеты в лесу и на больших дорогах, эдакий прообраз будущих экспроприаций - в сторону от столь «бесчестного дела» повернули многие.

Пока речь шла о жалобах и негодовании, такие беседы «за чашею вина», или «за рюмкой русской водки» готов был поддержать всякий обиженный. Пушкин в Десятой главе «Евгения Онегина» отмечал: 
«Сначала эти разговоры

Между лафитом и Клико

Лишь были дружеские споры,

И не входила глубоко

В сердиа мятежная наука,

Все это было только скука,

Безделье молодых умов,

Забава взросльх шалунов».

На рубеже, когда «мятежная наука» еще не «входила глубоко», отходили от «дружеских споров» многие из героев минувшей войны. В этом смысле показательна судьба Николая Мартемьяновича Сипягина, родившегося в 1785 г. Войну он закончил в звании начальника штаба авангардного корпуса Милорадовича, имея за спиной Бородино, Бауцен, Дрезден, Кульм, Лейпциг, взятие Парижа. Сразу после возвращения из Франции он был назначен начальником штаба Гвардейского корпуса и оставался в этой должности пять лет. Сипягин создал в гвардии библиотеки, основал типографию, выступил создателем «Военного журнала», организовывал школы для нижних чинов (Старк, 1995: 145-146).

Тогда же он стал членом одной из ранних, преддекабристских организаций «Общества военных людей», предназначенного для испытания перед вступлением в «Союз спасения». Для наших персонажей возможно было пребывание в каком-либо другом из подобных обществ - в «Когорте добромыслящих», как Бенкендорф, или в «Ордене русских рыцарей», как М. А. Дмитриев-Мамонов. Предварительно все они, находясь в походах, прошли через полковые масонские ложи - ведь где-то офицерам надо собираться - и встречались в ложе «Соединенных друзей», крайне далекой от серьезного «делания», но поощрявшем «разговоры между Лафитом и Клико». Так что после запрещения масонства в России в 1821 г. всем им пришлось дать подписку о не вступлении в будущем в тайные сообщества. Эта подписка удержала многих офицеров от присоединения к более поздним организациям декабристов.

Сипягин, прежде любимец Александра I, в 1819 г. был вынужден оставить пост и получил назначение с заметным понижением - командиром 6-й пехотной армейской дивизии в Ярославле. Женившись еще Петербурге, он с супругой уехал к новому месту службы, в провинцию, и там постепенно отошел от деятельности тайных обществ. Наличие семьи отвело от декабристских организаций целую плеяду полезных и активных членов, таких как генерал Шипов, командир нового Семеновского полка.

Отойдя от «забавы взрослых шалунов», следовало поразмыслить, что дальше? Женитьба, по мнению, царившему в офицерской среде, позволяла переключиться на некие, пока неведомые, но полезные для хозяй- 
ства дела. Семья мыслилась как замена привычному армейскому быту. А появление спутницы жизни, как утешение. По словам П. А. Вяземского, Пушкин отыскал в одной элегии два стиха: «Все неприятности по службе/ С тобой, мой друг я забывал»? - и называл их «самыми чисто русскими, самыми глубоко и верно прочувствованными» (Вересаев, 1986: 150-151).

Именно подобное настроение - забыть неприятности по службе толкало многих генералов в брак. Не по своей воле расставаясь с Оккупационным корпусом, Воронцов писал Закревскому: «Я к оной (службе. $-O$. E.) привык... проведши в оной лучшее время жизни моей, всякое другое состояние мне сперва покажется скучно: но нельзя с нею не расстаться, когда она сопряжена с унижением, и мне лучше будет не только быть вне оной, но хоть в пустыне, нежели всякий день ждать неприятность и быть трактованным, как последний человек». И позднее: «Ежели бы я был женат, то скорее бы привыкнул... а, между тем, служить как будто под наказанием, без всякой по совести причины, никак не могу» (Сборник Русского ..., 1890: 503).

Такое настроение не было сродни веселой свадебной кутерьме, которая охватила офицеров вслед за победой. Тогда генерал И. В. Сабанеев, представлявший старшее поколение отцов-командиров, с усмешкой писал Воронцову: «Мне кажется, после войны страсть к супружеству (страсть весьма благовидная) приметным образом начала действовать на воинов. Не жениться бы и мне?» (Архив князя Воронцова, 1894: 394) Сабанеев женился, да с громким скандалом, уведя супругу с детьми у полкового лекаря-пьяницы, а самого прогнав с глаз долой так далеко, что, когда встал вопрос о разводе, усиленные воинские команды не нашли любителя хлебнуть медицинского спирта и поколотить семью. Сабанеев приказал священнику обвенчать себя со спасенной лекаршей, усыновил детей, поселился на бессарабском хуторе и благоденствовал в недрах обретенного семейства. Спустя несколько лет этот брак был узаконен указом Николая I (Эйдельман, 2005: 112).

Снизу на позиции наших героев уже наступало поколение «младших братьев», у которого были свои представления о жизни. Долго делать вид, будто их совсем нет, не представлялось возможным. А согласиться с новыми веяниями - предать себя. Дело тут не в умении завязывать галстук а-ля Бромелл, или по-байроновски носить шейный платок «черный, как совесть грешника». Не в кудрях до плеч и не в длинных, как у дьявола, ногтях.

Дело в степени свободы, которую мог позволить себе дворянин, находясь на службе, и манкируя ею. Право не служить русское дворянство получило только в 1761 г. Однако продолжало поступать в полки и двигаться по «степеням известным», сохраняя за собой лишь нравственную возможность в любой момент выйти в отставку. Подобных случаев, если речь не 
шла о болезни или тяжелом ранении, было сравнительно немного.

А вот люди, которые считали, что проживут только со своих имений, никогда не поступая на службу, были совсем редки. «У русских нет представления о том, что такое джентльмен, - писал в 1829 г. английский путешественник Джеймс Александер, - они с подозрением смотрят на человека, который не называет свой чин и профессию. Однажды я слышал, как моего товарища допрашивали в таможне, пытаясь выяснить, кто он таков:

- Я английский джентльмен, - отвечал тот.

- А в каком вы чине? - спрашивал полицейский офицер.

- У меня нет никакого чина.

- Какая у вас профессия?

- Никакой?

- Как так?

- Я частное лицо.

- Но у вас ведь должен быть какой-то чин и какое-то занятие.

- Я живу на свой доход.

- Но это не ответ, сэр. Ради Бога, кто же вы?

- Ну хорошо, я член магистрата графства и помощник лордалейтенанта.

- Вот это другое дело, почему вы сразу не сказали?» (Александер, 2008: 55).

Такие люди старались, потеснив мир чинов, ввести новые правила игры, уже известные в Европе, но с трудом прививавшиеся дома. Там, где блюда «носили по чинам», тип «молодых генералов» господствовал. Но его время уже выходило.

Известную форму свободы наши герои позволяли себе, в казалось бы, безобидной сфере - языка. Большинство из них, даже обладатели немецких фамилий, демонстрировали подчеркнутую русскость. А. С. Грибоедов в «Горе от ума» нападал не только на незнание дворянами родного языка, но и на фраки:

Хвост сзади, спереди какой-то чудный выем,

Рассудку вопреки, наперекор стихиям...

Смешные, бритые, седые подбородки!

Как платья, волосы, так и умы коротки!..

Воскреснем ли когда от чужевластья мод?

Чтоб умный бодрый наш народ

Хотя по языку нас не считал за немцев».

Допетровская старина представлялась автору «Горя от ума» - временем более свободным. Тяготея к ней, он подчеркивал свой либерализм. На следствии по делу 14-го декабря Грибоедов показал, что предпочитал 
национальный костюм европейскому, что вызвало дополнительные вопросы: «С какою целью вы... неравнодушно желали русского платья и свободы книгопечатания?» Ответ был очевиден: «Русского платья желал я потому, что оно красивее и покойнее фраков и мундиров, а вместе с этим полагал, что оно бы снова сблизило нас с простотою отечественных нравов, сердцу моему чрезвычайно любезных. Я говорил не о безусловной свободе книгопечатания, желал только, чтобы она не стеснялась своенравием иных цензоров» (Следственное дело ..., 2001: 325-327).

В данном случае примечательно, что национальный костюм стоит на одной доске со свободой книгопечатания. В отчете III отделения за 1830 г., говорится: «Масса недовольных складывается из... так называемых русских патриотов, воображающих в своем заблуждении, что всякая форма правления может быть применена в России; они утверждают, что императорская фамилия немецкого происхождения, и мечтают о бессмысленных реформах в русском духе» (Россия под надзором, 2006: 73).

Русский «архаизм», часто выражавшийся именно в стремлении говорить и писать на родном языке с использованием коренных, «грубых» и простых оборотов речи, в 1820-е гг. связывался с радикализмом (Тынянов, 2001: 88).

Следует иметь в виду, что близкие взгляды в этот момент распространялись в Европе. Всю первую половину XIX в. либерализм уютно уживался с национализмом, революционные перемены мыслились одновременно с национально-освободительными в Польше, Италии, Германии, Венгрии, Греции, Латинской Америке. Имперские же ценности были прямо противоположны: неразличение национальности подданного при его скромных правах перед лицом монарха.

В России срастить национальную мысль с либеральной не удалось, хотя среди декабристов было множество пламенных патриотов. В десятой главе об этом сказано:

«Одну Россию в мире видя,

Преследуя свой идеал,

Хромой Тургенев им внимал

И, плети рабства ненавидя,

Предвидел в сей толпе дворян

Освободителей крестьян».

Однако соединить высокие помыслы о родине с «цареубийственным кинжалом» не получились.

И позднее у Некрасова можно встретить отголоски этого же настроения, например, в песне Гриши Добросклонова: «Потомок татар, как кона выводил, на рынок раба-славянина». Речь о дворянах - отпрысках ордынцев, и крепостных - далеких правнуках древнерусских свободных земле- 
пашцев. Картина исторически неверная, но популярная в позапрошлом столетии. Славянофильство рассматривалось властью как либеральный национализм.

Тогдашнее коренное дворянство очень жаловалось на немцев. Английский посланник Эдвард Дисборо, чем Меморандум о событиях на Сенатской площади мы уже приводили, помимо прочего писал: «Они - дворянство - жаловались на засилье иноземцев: что немецкий интендант назначен министром финансов, что иностранные дела поручены греку и потомку ливонца, рожденного на борту британского корабля, что послом в Лондоне - ливонский барон, в Париже - корсиканский авантюрист, в Берлине финн, англичанин командует на Черном море, и помимо этого множество мелких назначений» (Подлинные письма, 2011: 84).

Речь идет об очень видных сановниках: Е. Ф. Канкрине, И. А. Каподистрии, К. В. Нессельроде, Х. А. Ливене, К. А. Поццо ди Борго, Д. А. Алореусе, А. С. Грейге. Такие люди теснили коренную знать.

Александер не без удивления писал, что русские не любят, когда к имени Екатерины II добавляется эпитет «Великая»: «Мне постоянно напоминали, что она чересчур явно проявляла свое пристрастие к иностранцам, потому что сама была немкой... Русские говорят: “Нас заедают немцы”, и... полагают, что вполне могут обойтись без иностранцев» (Александер, 2008: 90).

После 1825 г. происходил двусторонний процесс внедрения русского языка в повседневную дворянскую жизнь. Развивалась литература, толстые журналы читало все больше людей. В отчете III-го отделения за 1830 г., например, сказано: «Высшие слои общества у нас чужды национальной литературе (имелись в виду те самые новые аристократы. - О. Е.), но весь средний класс, молодежь, военные, даже купцы, все принимают близко к сердцу ее преуспеяния, все писатели имеют своих многочисленных сторонников, которые взирают на них, как на оракулов общественного мнения, повторяют их рассуждения и усваивают их мировоззрение» (Россия под надзором ..., 2006: 66).

В то же время, правительство насаждало русский в качестве повседневного в учебных заведениях и в учреждениях. А. О. Смирнва-Россет вспомнила, что при знакомстве с Пушкиным удивила его своим хорошим русским: «Как вы хорошо говорите по-русски». - «Еще бы, мы в институте всегда говорили по-русски, нас наказывали, когда мы в дежурный день говорили по-французски» (Смирнов-Россет, 2005: 543). Эту практику в Смольном монастыре ввели именно после 14-го декабря, когда Николай I услышал, что в роковой день воспитанницы, перепуганные пушечкой канонадой, кричали по-французски, не зная родного языка.

Император пошел навстречу про-русским настроениям общества. 
В том же 1833 г. ее величество и дамы, представленные ко двору среди них, надо полагать, и Татьяна (супруге служившего в столице генерала такая привилегия доступна) - показались публике в русских национальных платьях - стилизованных нарядах, сочетавших модный крой с традиционными аксессуарами. «Независимо от красоты сего одеяния оно по чувству национальности возбудило всеобщее одобрение. Многие изъявляют желание видеть дальнейшее преобразование и в мужских наших нарядах, и судя по общему отголоску, можно наверное сказать, что таковое преобразование сближением наших мундиров к покрою одеяния наших бояр прежнего времени было бы принято с крайним удовольствием» (Россия под надзором ..., 2006: 114).

Как не вспомнить Грибоедова? Событие оказалось запечатлено Бестужевым-Марлинским в письме княгини Веры из «Фрегата “Надежды” : «На мне было глазетовое платье, которое не знаю почему, называют при дворе русским, испод белый, атласный с золотом. Что за фасон, что за шитье! Хоть бы на колени встать перед ним!» (Бестужев-Марлинский, 1986: 347)

Дело не в одних платьях. При Николае I происходит первая историческая реставрация Московского Кремля, по государственному заказу создает свои рисунки царских регалий Ф. Г. Солнцев, собираются археологические коллекции домонгольских древностей, для общего обозрения выставляются игрушки и учебники царских детей времен Алексея Михайловича. Допетровская старина возбуждает живейший интерес. Все это отвечало личным вкусам государя, а, кроме того, согласовывалось с умонастроениями общества. Появилось противоположное аристократическому либерализму течение - сращение национального и имперского начал.

Восстание в Польше 1830 г. подействовало на этот раствор как закрепитель. В русской офицерской среде мигом ожили старые обиды, память о том, что поляки воевали на стороне Наполеона и не были за это наказаны... «Первое мнение неумолимых русских патриотов, желающих суворовской резни, уничтожения конституции, разделения королевства на русские провинции и раздачи имений участников восстания и староств генералам и другим русским чиновникам» (Россия под надзором ..., 2006: 70).

У роковой черты 1825 г. наши герои повели себя очень по-разному. Абсолютное большинство поддержало нового императора. Даже те немногие, кто был связан с тайными обществами. Николай I в речи на приеме дипломатического корпуса 20 декабря 1825 г. упомянул их: «Найдутся безусловно виновные, как, например, князь Трубецкой, но еще более значительно число людей, введенных в заблуждение, которые не знали, куда их ведут. В прошлый понедельник вокруг меня было несколько молодых офицеров, прекрасно исполнявших свой долг и без колебания атаковав- 
ших ряды мятежников; между тем, многие их них участвовали в заговоре или, по крайней мере, знали о нем, но, будучи связаны страшными клятвами, исторгнутыми у их молодости и неопытности, они полагали, что честь воспрещает им разоблачить его» (Император ... , 2002: 120).

Это слова о кавалергардах, среди которых нашлись причастные, например, поручик И. А. Анненков, которые не примкнули к восставшим. Командир бригады Алексей Орлов несколько раз сам водил конницу в атаку на мятежников. В конных атаках участвовал и Бенкендорф, и другие старые генералы-кавалеристы. Накануне похолодало, лошади, кованные полетнему, поскальзывались на льду, всадники падали, еще не доскакав до «противника». Ушибов и переломов у кавалергардов было больше, чем ран. Они же преследовали и отступавших по Галерной улице пехотинцев.

Не изменили присяге и коренные полки, которыми руководимые братьями Шиповыми, еще вчера активные члены тайного общества. Князь Трубецкой передал разговор с С. П. Шипоавм, новым командиром семеновцев, которого старался склонить к выступлению. Шипов отнекивался: «Большое несчастье будет, если Константин будет императором». Трубецкой возражал: «Но Николай человек жестокий». Шипов его мнения не разделял: «Этот человек просвещенный, а тот варвар» (Брюханов, 2004: 219).

Так что в роковой день на Сенатской площади дела обстояли очень неоднозначно. Сам факт смерти Александра I разоружил многих недовольных. Они готовы были предъявить претензии к прежнему императору, а новый еще не успел им ничего сделать. Близость к заговору вовсе не определяла поведения человека у роковой черты.

Как повели себя жены наших героев. Общие тайны сближают, если они открыты между супругами. И, напротив, отдаляют, если остаются достоянием одного: каждый купается в своих страхах и подозрениях. Последняя картина раскрыта в писымах родным от Марии Волконской после ее свадьбы с князем Сергеем. Муж казался «неровен», «резок», «несносен», о чем-то молчал (Филин, 2006: 136). Между тем разворачивались последние месяцы перед восстанием, и Волконскому больше дела было в Умани, где стояла его дивизия, чем рядом с любимой женщиной, которой он к тому же не мог открыться.

Большинство жен, в отличие от Марии Волконской, либо знало, либо догадывалось о том, что тяготит супругов. Иные, как Софья Киселева, хотели видеть в них мучеников и были разочарованы тем, что не пришлось целовать оковы (Третьякова, 2006: 51). Другие предпочли целовать живых и ни во что не замешенных людей.

Зададимся вопросом, на что готовы были подобные женщины для своих мужей? И отвечать станем, оставив в стороне щекотливый предмет верности: среди генеральш встречались и Татьяны, и Земфиры. Однако 
удивителен тот факт, что непохожие друг на друга дамы в отношении совсем разных по характеру, достоинствам и судьбе супругов поступали сходным образом. Не бросали в трудную минуту.

Когда в 1823 г. Е. К. Воронцова узнала, что после очередных маневров ее супруг не получил чин полного генерала, который ждал уже 11 лет (Удовик, 2004: 141-142, 144, 150-151), она на последнем месяце беременности отправилась к нему в Одессу от матери из Белой Церкви по душной осенней степи, в тряской карете. К этому времени Воронцовы уже потеряли двоих детей, и такое путешествие могло окончиться для графини плачевно. Супруг не сообщал ей о неприятности, и, надо думать, Елизавета Ксаверьевна обо всем догадалась сама, прочтя о новых производствах в «Ведомостях». Это поступок преданной женщины, к тому же очень хорошо понимавшей душевное состояние супруга.

В 1823 г., когда А. А. Закревский, памятуя о Семеновской истории, был назначен генерал-губернатором Финляндии и удален из Петербурга в Або, его жена, та самая ветреная Аграфена Закревская, которую Пушкин и Вяземский называли «Медной Венерой», бросила в Италии принца Леопольда Кобургского, будущего короля Бельгии, и поспешила в чухонские края, утешать супруга (Вересаев, 2001: 147). Впрочем, говорили и обратное - поскольку Леопольд намеревался, ради короны, жениться на английской принцессе Шарлотте, Закревская порвала с ним и вернулась к супругу. Для Пушкина те события остались памятны эпиграммой на изгнанных, которую он позднее спел Смирновой-Россет: «А Закревский баба,/ Удалился в Або,/ А другая баба - начальником штаба» (СмирноваРоссет, 1989: 511).

За мужем уедет в Сибирь Мария Волконская. Ее сестра Екатерина, которую за властный характер Пушкин называл Марфой Посадницей и уверял, что Марина Мнишек написана с нее, останется с потерявшим царскую милость, не осужденным по делу 14-го, но очень замешенным Михаилом Федоровичем Орловым. Оправдывая поступок сестры, она будет писать брату Александру, что та «сможет найти счастье в своей преданности к мужу, в выполнении своих обязанностей по отношению к нему» (Филин, 2006: 159).

Примеры можно множить.

Значит, было за этими людьми что-то, заставлявшее женщин жертвовать собой и забывать минутные увлечения.

Настроение в обществе, нетерпеливое ожидание перемен, домашние недомолвки заставляли жен догадываться о том, о чем знали многие. Александр Тургенев записал в дневнике отрывки двух разговоров с поэтом в декабре 1836 и в январе 1837 гг.: «Вчера у Пушкиных до полуночи... о Михаиле Орлове, о Киселеве, Ермолове и князе Меншикове. Знали и ожидали, “без нас не обойдутся”» (Тургенев, 2005: 589). Близко вращаясь 
в сановной среде, поэт более точно повторил то, что было ему известно и перед выступлением 14-го. «Правительство... в журналах объявило опалу и тем, которые, имея какие-нибудь сведения о заговоре, не объявили о том полиции, - писал он в январе 1826 г. В. А. Жуковскому. - Но кто же, кроме полиции и правительства, не знал о нем? О заговоре кричали по всем переулкам» (Пушкин, 1962b: 223).

Военная среда была пронизана нитями заговора. Крупные рыбины не рисковали собой, без особой необходимости: сначала возьмите власть, позовите нас, и мы посмотрим. Повторим, большинство не изменило присяге. Что их ждало за порогом нового царствования? Вторичное временное возвращение «в ряды» - и их отставки, и с гражданской службы.

При покойном императоре Россия как бы почивала на лаврах. После декабрьских событий ее прочность начали пробовать на зуб, выпуская вперед восточных соседей, у которых всегда имелись претензии по границе. Еще во время коронации молодого императора началась война с Персией, под ударом которой корпус Ермолова не выдержал. Пришлось послать И. Ф. Паскевича. Почти сразу без передышки в дело вступили турки. «Его венец не из роз», - писал о государе Д. Н. Блудов. А впереди были польские волнения, холерные бунты и мятежи в военных поселениях. В каждом из этих событий так или иначе принимали участие генералы старой когорты.

Пала Варна, Силистрия, турецкой армии было нанесено поражение при Кулевчи, Киселев подошел к Шипкинскому перевалу и предлагал захватить Софию, без боя пал Адрианополь. На Кавказе войска Паскевича захватили Анапу, Ардаган, Ахалцих, Поти Баязет, Эрзерум, Бейбурт и готовились наступать на Батум и Трапезунд.

Однако даже выгодный мир с Турцией не положил конец испытаниям. Напротив, они только начинались. «Стечение печальных обстоятельств, эпидемия, плохой урожай, застой в торговле, бедность, революция (во Франции. - О. Е.) - все эти бедствия создали всеобщее тяжелое настроение, - сказано в отчете III отделения за 1830 г., - которым пользуются злонамеренные люди и интриганы для того, чтобы посеять сомнения относительно будущего и предсказать репрессии... Они стараются распускать ложные и тревожные слухи, искажают... характер Государя, проповедуя недоверие и страх за будущее и рисуя монарха деспотом, не уважающим ни закон, ни личную неприкосновенность» (Россия под надзором ..., 2006: 72).

Итак, переход заметной часто военной элиты на гражданскую службу занял в России после Наполеоновских войн порядка двух десятилетий. Он начался сразу после вывода Оккупационных корпусов из Европы и продолжался еще в начале николаевского царствования. Его подхлестывала необходимость срочно менять ключевые кадры гражданской адми- 
нистрации, запятнавшие себя коррупцией. Однако процесс был прерван войнами с Персией, Турцией и Польшей, когда часть офицеров снова оказались востребованы в действующей армии. Позднее те же люди либо окончательно вышли в отставку, либо вернулись к должностям в составе имперской бюрократии.

Благодаря названным кадрам, удалось существенно умерить аппетиты местных чиновников и провести ряд реформ николаевского царствования, в частности, реформу государственных крестьян 1837 г. Для самих бывших офицеров уход с постов в гвардии и армейских дивизиях оказался поводом для расставания с масонскими и ранними декабристскими организациями, куда они попали во время войны или сразу после нее, служа в гарнизонах. Удачные брак и получение гражданской должности позволило многим избежать обществ военных заговорщиков и продолжить службу в следующем царствовании.

\section{СПИСОК ЛИТЕРАТУРЫ}

Александер, Дж. (2008) Россия глазами иностранца. М.: Аграф.

Арабоглы, М. А. (2006) Три усадьбы, три судьбы. СПб.: Искусство

Архив князя Воронцова (1894) : в 40 томах. М.: Тип. Грачева и К. Т. 39.

Бандурин, С. Г., Португальский, Р. М. (2006) Пограничная элита Российской империи. М.: Издательский дом «Граница».

Бантыш-Каменский, Д. Н. (1840) Биографии российских генералиссимусов и генерал-фельдмаршалов. СПб.: Тип. 3-го Департамента Министерства Государственных Имуществ.

Бенкендорф, А. Х. (2012) Воспоминания. М.: Российский фонд культуры.

Бестужев-Марлинский, А. А. (1986) Повести. М.: Правда.

Брюханов, В. А. (2004) Заговор графа Милорадовича. М.: АСТ.

Бутурлин, М. Д. (1897) Записки // Русский архив. Кн. 3. № 1. М.: Тип. Лазаревского института восточных языков

Вересаев, В. В. (1986) Пушкин в жизни. Минск: Мастацкая литератуpa.

Вересаев, В. В. (2001) Спутницы Пушкина. М.: Профиздат

Вигель, Ф. Ф. (2003а) Записки : в 2 книгах. М.: Захаров. Кн. I.

Вигель, Ф. Ф. (2003b) Записки : в 2 книгах. М.: Захаров. Кн. II.

Волконский, С. Г. (1902) Записки. СПб.: Синодальная тип.

Вульф, А. Н. (2005) Записки // Пушкин в воспоминаниях современников. М.: Захаров.

Давыдов, М. А. (2005) Оппозиция его величества. М.: Зебра Е.

Дашкова, Е. Р. (2001) Письмо Уильяму Робертсону. 9 октября 1776 г. // 
Дашкова Е. Р. О смысле слова «воспитание». Сочинения, письма, документы. СПб.: Дмитрий Буланин.

Записки Бенкендорфа (2001). Отечественная война 1812 г. Освобождение Нидерландов. М.: Языки славянской культуры.

Знаменитые россияне XVIII - XIX веков (1996). СПб.: Лениздат.

Из донесений М. Я. Фон-Фока (2001) // Фонвизин Д. М., Грибоедов А. С. Пьесы. М.: Художественная литература.

Император Николай Первый (2002). М.: Русский мір.

Карнухина, Л. (2005) Государственный музей А. С. Пушкина, Москва. М.: Государственный музей А. С. Пушкина.

Липранди, И. П. (2005) Записки // Пушкин в воспоминаниях современников. М.: Захаров.

Лорер, Н.И. (1984) Записки декабриста. Иркутск: Восточно-Сибирское книжное издательство.

Лотман, Ю. М. (2003) Пушкин. СПб.: Искусство.

Муравьев, Н. Н. (1989) Записки // Русские мемуары 1800-1825. М.: Правда. $\mathrm{Ta}+$.

Нерсесов, Я. Н. (2012а) Главные битвы наполеоновских войн. М.: Аван-

Нерсесов, Я. Н. (2012b) Русские генералы 1812 года. М.: Аванта+.

Николай I (2002). Записки // Николай Первый и его время. Документы. Мемуары : в 2 томах. М.: Олма-пресс. Т. I.

Олейников, Д. И. (2009) Бенкендорф. М.: Молодая гвардия.

Ольга Николаевна, великая княжна (2008). Сон Юности // Боханов А. Н. Николай І. М.: Вече.

Подлинные письма из России (2011). 1825-1828. СПб.: Дмитрий Буланин.

Пушкин, А. С. (1962a) Собрание сочинений : в 10 томах. М.: Художественная литература. Т. V.

Пушкин, А. С. (1962b) Собрание сочинений : в 10 томах. М.: Художественная литература. Т. IX.

Россия под надзором (2006). Отчеты III отделения 1827-1869. М.: Российский фонд культуры.

Русский Архив (1912). СПб.: Тип. Лазаревского института восточных языков. Т. II.

Русский литературный анекдот конца XVIII - начала XIX века (1990). М.: Художественная литература.

Сборник Русского Исторического Общества (1890). СПб.: Тип. М.М. Стасюлевича. Т. 73.

Следственное дело А. С. Грибоедова (2001) // Грибоедов, А. С. Пьесы. М.: Художественная литература. 
Смирнова-Россет, А. О. (1989) Дневник. Воспоминания. М.: Наука.

Смирнова-Россет, А. О. (2005) Записки // Пушкин в воспоминаниях современников. М.: Захаров.

Соболевский, С. А. (2005) Воспоминания // Пушкин в воспоминаниях современников. М.: Захаров.

Старк, В. П. (1995) Портреты и лица. СПб.: Искусство.

Третьякова, Л. И. (2006) Вечный идол. М.: Виконт-МВ.

Тургенев, А. И. (2005) Записки // Пушкин в воспоминаниях современников. М.: Захаров.

Тынянов, Ю. Н. (2001) История литературы. Критика. СПб.: Азбукакласика.

Удовик, В. А. (2004) Воронцов. М.: Молодая гвардия.

Фикельмон, Д. (2009) Дневник 1829-1837. М.: Минувшее.

Филин, М. Д. (2006) Мария Волконская. М.: Молодая гвардия.

Фок, М. Я. (2002) Донесения А. Х. Бенкендорфу // Николай Первый и его время : в 2 томах. М.: Олма-пресс. Т. 2.

Чукарев, А. Г. (2005) Тайная полиция России: 1825-1855. М.: Кучково поле.

Эйдельман, Н. Я. (2005) Первый декабрист. М.: Вагриус.

Елисеева Ольга Игоревна - кандидат исторических наук, доцент кафедры истории Московского гуманитарного университета. Адрес: 111395, Россия, г. Москва, ул. Юности, д. 5, корп. 3. Тел.: +7 (499) 374-55-81. Эл. адрес: historymosgy@mail.ru

Eliseeva Olga Igorevna, Candidate of History, Associate Professor, Department of History, Moscow University for the Humanities. Postal address: Bldg.3, 5 Yunosti St., 111395 Moscow, Russian Federation. Tel.: +7 (499) 37455-81.E-mail: historymosgy@mail.ru 